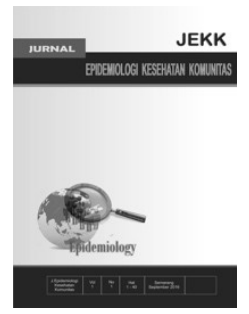

\title{
Beberapa Faktor Risiko Kejadian Penyakit Ginjal Kronik (PGK) Stadium V pada Kelompok Usia Kurang dari 50 Tahun (Studi di RSUD dr.H.Soewondo Kendal dan RSUD dr.Adhyatma,MPH Semarang)
}

Ariyanto",Suharyo Hadisaputro ${ }^{* *}$, Lestariningsih ${ }^{* * *}$, Sakundarno Adi****,Selamat Budijitno ${ }^{* * *}$

"Kantor Kesehatan Pelabuhan Kelas II Semarang,**Politeknik Kesehatan Semarang

${ }^{* * *}$ Fakultas Kedokteran Undip ${ }^{* * * *}$ Fakultas Kesehatan Masyarakat Undip

\begin{abstract}
Background : Chronic Kidney Disease (CKD) stage V is an end-stage chronic kidney disease characterized by glomerular filtration rate less than $15 \mathrm{~mL} / \mathrm{min} / 1.73 \mathrm{~m} 2$ and require dialysis therapy. The purpose of this study to prove risk factors the occurrence of CKD Vin the age group of less than 50 years.
\end{abstract}

Method : This study was a mixed method, case-control studies design werereinforced with indepht interview. Total respondents were 124 (62 cases and 62 controls) that taken by consecutive sampling. Research instrument was a questionnaire interview. Data analysis using univariate, bivariate (chi-square) and multivariate (logistic regression).

Result : The variables that proved to be a risk factor for CKD V in the age group of less than 50 years weresupplement energy drink consumption $>4$ times/week $(\mathrm{p}=0.038 ; 95 \% \mathrm{CI}=1.063$ 7.944; $\mathrm{OR}=2.905)$, smoking $\geq 10$ ciggarets/day $(\mathrm{p}=0.011 ; 95 \% \mathrm{CI}=1.384-11.920 ; \mathrm{OR}=4.061)$, and herbal medicine consumption $>4$ times/week ( $\mathrm{p}=0.007 ; 95 \% \mathrm{CI}=1.431-9.949 ; \mathrm{OR}=3.773)$. Variables that not provedwere the consumption of coffee, supplements of vitamin C, soft drinks, alcohol, and NSAIDs. Qualitative results stated that the respondents consumed energy drink supplements to increase their stamina, smoke because it has become a habit, and consume herbal medicinesbecause seen more natural and cure the sciatica fastly.

Conclusion : Risk factors for the occurrence of CKD V in the age group of less than 50 years were the supplement energy drink consumption $>4$ times/week, smoking $\geq 10$ ciggarets/day, and the consumption of herbal medicine $>4$ times/week.

Keywords : PGK V;risk factors;age less than 50 years; the energy supplement drink; smoke.

*Penulis korespondensi : ariyanto_19@yahoo.com

\section{Pendahuluan}

Penyakit Ginjal Kronik (PGK) stadium V merupakan Penyakit Ginjal Kronik stadium akhir yang ditandai dengan laju filtrasi ginjal kurang dari $15 \mathrm{ml} / \mathrm{menit} / 1,73$ $\mathrm{m} 2$ dan memerlukan terapi dialisis. ${ }^{1}$ Pada derajat awal, penyakit ginjal kronik belum menimbulkan gejala dan tanda, bahkan laju filtrasi glomerulus sebesar $60 \%$ pasien 
masih asimtomatik tapi sudah terjadi peningkatan kadar urea dan kreatinin serum. Kelainan secara klinis dan laboratorium baru terlihat dengan jelas pada stadium 3 atau $4 .^{2}$ Penyakit ginjal kronik menjadi masalah besar dunia karena sulit disembuhkan, biaya perawatan dan pengobatannya yang terhitung mahal. ${ }^{3}$ Prevalensi pasien PGK V di dunia pada tahun 2014 cukup tinggi yaitu sebanyak 0,13\% (sekitar 10 juta jiwa), dari jumlah tersebut sekitar $40 \%$ diantaranya berada pada usia kurang dari 50 tahun. ${ }^{4}$ Prevalensi PGK V di Indonesia sebanyak 0,08\% (sekitar 200.000 orang), $48 \%$ diantaranya berusia kurang dari 50 tahun. ${ }^{5}$ Jumlah kematian akibat PGK di dunia yaitu sekitar 850.000 orang setiap tahunnya. Angka kematian PGK stadium V dapat mencapai $100 \%$ jika tidak dilakukan terapi pengganti ginjal, sedangkan angka kematian PGK stadium Vsecara umum yang menjalani hemodialisis pada tahun pertama yaitu sekitar $10 \%$, dan meningkat pada tahun-tahun berikutnya. ${ }^{4}$ Secara fisiologis, mulai usia 50 tahun ginjal akan mengalami penurunan fungsi cukup signifikan akibat berkurangnya jumlah nefron yaitu sekitar $20 \%$. ${ }^{6}$ Selain itu adanya penyakit degeneratif sebagai faktor risiko terkuat penyebab PGK stadium $\mathrm{V}$ yaitu hipertensi dan diabetes mellitus paling banyak diderita pada kelompok usia 50 tahun ke atas. ${ }^{7}$ Jika kejadian penyakit ginjal kronik terjadi pada usia yang lebih dini maka dimungkinkan karena gaya hidup yang tidak sehat terutama yang berkaitan dengan kebiasaan konsumsi zat-zat tertentu yang bersifat nefrotoksik. ${ }^{6}$

Faktor kebiasaan konsumsi minuman atau zat tertentu yang diduga berhubungan dengan kejadian PGK V yaitu kebiasaan konsumsi kopi, minuman suplemen energi, suplemen vitamin $\mathrm{C}$, minuman bersoda/ soft drink, merokok, konsumsi obat AINS (Anti Inflamasi Non Steroid), dan obat herbal. Belum banyak penelitian tentang faktor kebiasaan konsumsi minuman atau zat tertentu terhadap kejadian PGK V pada kelompok usia kurang dari 50 tahun. Faktor tersebut merupakan faktor yang dapat dikendalikan untuk mencegah progresivitas menuju PGK stadium V.

\section{Metode}

Penelitian ini merupakan penelitian mix method yaitu penggabungan penelitian secara observasion alanalitik dengan metode penelitian kasus kontrol (case-control) ditunjang dengan penelitian kualitatif. $^{8}$ Penelitian dengan desain kasus kontrol untuk mengkaji hubungan antara efek tertentu dengan faktor risiko tertentu. Kasus adalah pasien PGK $\mathrm{V}$ yang menjalani hemodialisis dan kontrol adalah pasien PGK stadium awal., ${ }^{1,2}$ Penelitian kualitatif dilakukan dengan teknik indepht interview.

Penelitian dilaksanakan pada bulan Mei-Juli 2016. Populasi kasus adalah semua pasien PGK V yang menjalani hemodialisis di RSUD dr. Soewondo Kendal dan RSUD dr.Adhyatma, MPH, Semarang. Populasi kontrol adalah pasien PGK awal yang berobat di kedua RS tersebut. Besar sampel dalam penelitian ini adalah 62 kasus dan 62 kontrol dan metode pengambilan sampel yang digunakan adalah dengan cara consecutive sampling dimana setiap pasien PGK yang memenuhi kriteria penelitian dimasukkan dalam penelitian sampai kurun waktu tertentu, sehingga jumlah sampel yang diperlukan terpenuhi.

Wawancara mendalam dilakukan terhadap $10 \%$ dari kasus dan kontrol yang dipilih secara acak sederhana. Kriteria inklusi kasus adalah pasien PGK V yang menjalani hemodialisis di unit hemodialisis RSUD dr.H.Soewondo Kabupaten Kendal dan RSUD dr. Adhyatma, MPH Semarang pada masa penelitian, berusia kurang dari 50 tahun, dan bersedia menjadi responden. Kriteria eksklusi kasus yaitu pasien dalam keadaan lemah atau tidak memungkinkan untuk diwawancarai, PGK yang disebabkan karena kelainan ginjal bawaan/kongenital, dan pasien pernah mendapatkan transplantasi ginjal.

Variabel terikat dalam penelitian ini adalah kejadian PGK stadium $\mathrm{V}$ dan variabel bebas dalam penelitian ini terdiri dari konsumsi kopi, minuman suplemen 
energi, suplemen vitamin $\mathrm{C}$, minuman bersoda, alkohol, rokok, obat AINS (Anti Inflamasi Non Steroid), dan obat herbal. Variabel confounding dalam penelitian ini yaitu umur, jenis kelamin, riwayat keluarga, riwayat $\mathrm{DM}$, riwayat hipertensi, riwayat Infeksi Saluran Kemih (ISK), riwayat Batu Saluran Kemih (BSK), riwayat hepatitis $\mathrm{B} / \mathrm{C}$, dan riwayat hiperurisemia. Pengolahan dan analisis data dilakukan dengan system komputer program SPSS for window terdiri dari analisis univariat, bivariat dan multivariat.

\section{Hasil}

Pada Tabel 1. menunjukkan bahwa tingkat pendidikan responden paling banyak yaitu tamat SMP sebanyak 41 responden $(33,1 \%)$. Pekerjaan yang dimiliki responden paling banyak yaitu karyawan swasta sebanyak 35 responden (28,2\%). Hasil analisis bivariat berbagai variabel independen dan confounding disajikan pada Tabel 2. Pemodelan akhir faktor risiko kejadian PGK V disajikan pada Tabel 3.

Tabel 1. Karakteristik Responden Menurut Pendidikan dan Pekerjaan di RSUD dr.H.Soewondo Kendal dan RSUD dr. Adhyatma, MPH Semarang $(n=124)$.

\begin{tabular}{clrr}
\hline Variabel & Kategori & f & \multicolumn{1}{c}{$\%$} \\
\hline \multirow{4}{*}{ Pendidika } & Tamat SD & 36 & 29,0 \\
$\mathrm{n}$ & Tamat SMP & 41 & 33,1 \\
& Tamat SMA & 34 & 27,4 \\
\cline { 2 - 4 } & Tamat Perguruan & 13 & 10,5 \\
& Tinggi & & \\
\hline \multirow{5}{*}{ Pekerjaan } & Buruh & 20 & 16,1 \\
& Petani & 11 & 8,9 \\
& Wiraswasta & 23 & 18,5 \\
& Karyawan Swasta & 35 & 28,2 \\
& Sopir & 9 & 7,3 \\
& PNS/TNI/POLRI & 6 & 4,8 \\
& TKI & 6 & 4,8 \\
& Tidak Bekerja & 14 & 11,3 \\
\hline
\end{tabular}

Hasil analisis bivariat, menunjukkan bahwa variabel independen yang berhubungan dengan kejadian PGK V yaitu konsumsi minuman suplemen energi $(\mathrm{p}=0,000 ; \quad \mathrm{OR}=4,570)$, konsumsi alkohol $(\mathrm{p}=0,008 ; \mathrm{OR}=6,471)$, merokok $(\mathrm{p}=0,001$; $\mathrm{OR}=3,979)$, dan konsumsi obat herbal $(p=0,006 ; O R=3,009)$. Variabel confounding yang berhubungan dengan kejadian PGK V yaitu riwayat hipertensi $\quad(p=0,012$; $\mathrm{OR}=2,510)$ dan riwayat batu saluran kemih $(\mathrm{p}=0,036 ; \mathrm{OR}=2,476)$.

Analisis regresi logistik untuk mengetahui variabel yang menjadi prediktor terjadinya PGK V. Variabel yang dijadikan kandidat dalam uji regresi logistik ini adalah variabel dari hasil uji chi square dengan nilai $\mathrm{p}<0,25$. Ada 5 (lima) variabel yang masuk dalam kandidat analisis regresi logistik, yaitu konsumsi kopi, konsumsi minuman suplemen energi, konsumsi alkohol, merokok, dan konsumsi obat herbal. Sedangkan variabel confounding yang menjadi kandidat dan masuk dalam pemodelan multivariat yaitu riwayat hipertensi dan riwayat batu saluran kemih.

Tabel 2. Rangkuman Hasil Analisis Bivariat Variabel Independen dan Variabel Confounding Terhadap Kejadian PGK V di RSUD dr.H.Soewondo Kendal dan RSUD dr.Adhyatma, MPH Semarang

\begin{tabular}{lccc}
\hline \multicolumn{1}{c}{ Variabel } & $p$ & OR & $95 \%$ CI \\
\hline $\begin{array}{l}\text { Konsumsi } \\
\text { kopi } \geq 2 \\
\text { kali/hari }\end{array}$ & $0,208^{*}$ & 1,705 & $0,739-$ \\
\hline $\begin{array}{l}\text { Konsumsi } \\
\text { minuman }\end{array}$ & $0,000^{* *}$ & 4,570 & $1,971-$ \\
$\begin{array}{l}\text { suplemen } \\
\text { energi }>4\end{array}$ & & & 10,593 \\
kali/minggu & & & \\
\hline $\begin{array}{l}\text { Konsumsi } \\
\text { suplemen } \\
\text { vitamin C }>4\end{array}$ & 0,510 & 1,554 & $0,416-$ \\
kali/minggu & & & 5,800 \\
\hline $\begin{array}{l}\text { Konsumsi } \\
\text { minuman } \\
\text { bersoda }>4\end{array}$ & 0,409 & 1,585 & $0,528-$ \\
kali/minggu & & & 4,757 \\
\hline $\begin{array}{l}\text { Konsumsi } \\
\text { alkohol }>4\end{array}$ & $0,008^{* *}$ & 6,471 & $1,370-$ \\
kali/minggu & & & 30,553 \\
\hline $\begin{array}{l}\text { Merokok } \geq \\
10 b a t a n g / \\
\text { hari }\end{array}$ & $0,001^{* *}$ & 3,979 & $1,667-$ \\
\hline
\end{tabular}




\begin{tabular}{llll}
\hline $\begin{array}{l}\text { Konsumsi } \\
\text { obat AINS } \\
>4 \text { kali/ } \\
\text { minggu }\end{array}$ & 0,347 & 1,562 & $0,614-$ \\
& & & 3,977 \\
\hline $\begin{array}{l}\text { Konsumsi } \\
\text { obat herbal } \\
>4 \mathrm{kali} / \\
\text { minggu }\end{array}$ & $0,006^{* *}$ & 3,009 & $\begin{array}{l}1,343- \\
6,745\end{array}$ \\
\hline \multicolumn{1}{c}{ Variabel } & & & \\
$\begin{array}{l}\text { confounding } \\
\text { Ada riwayat }\end{array}$ & $0,012^{* *}$ & 2,510 & $1,218-$ \\
hipertensi & & & 5,172 \\
\hline $\begin{array}{l}\text { Ada riwayat } \\
\text { batu saluran } \\
\text { kemih }\end{array}$ & $0,036^{* *}$ & 2,476 & $1,047-$ \\
& & & 5,858 \\
\hline
\end{tabular}

Tabel 3. Hasil Pemodelan Akhir Faktor Risiko Kejadian PGK V di RSUD dr.H.Soewondo Kendal dan RSUD dr.Adhyatma, MPH Semarang.

\begin{tabular}{lcccc}
\hline \multicolumn{1}{c}{ Variabel } & $\begin{array}{c}\text { Koefisien } \\
\text { B }\end{array}$ & $p$ & OR & $95 \%$ CI \\
\hline $\begin{array}{l}\text { Konsumsi } \\
\text { minuman } \\
\text { suplemen } \\
\text { energi }>4 \\
\text { kali/ } \\
\text { minggu }\end{array}$ & 1,067 & 0.038 & 2,905 & $1,063-$ \\
7,944 & \\
\hline $\begin{array}{l}\text { Merokok } \geq \\
10 \text { batang/ }\end{array}$ & 1,401 & 0,011 & 4,061 & $1,384-$ \\
hari & & & & 11,920 \\
\hline $\begin{array}{l}\text { Konsumsi } \\
\text { obat herbal }\end{array}$ & 1,328 & 0,007 & 3,773 & $1,431-$ \\
$>\begin{array}{l}>\text { kali/ } \\
\text { minggu }\end{array}$ & & & & 9,949 \\
\hline $\begin{array}{l}\text { Ada } \\
\text { riwayat } \\
\text { hipertensi }\end{array}$ & 1,544 & 0,001 & 4,684 & $1,851-$ \\
\hline $\begin{array}{l}\text { Ada } \\
\text { riwayat } \\
\text { batu } \\
\text { saluran } \\
\text { kemih }\end{array}$ & 1,322 & 0,017 & 3,789 & $1,266-$ \\
\hline Constant & $-5,244$ & 0,000 & & \\
\hline
\end{tabular}

Hasil pemodelan akhir uji regresi logistik menunjukkan bahwa terdapat hubungan antara konsumsi minuman suplemen energi $>4 \mathrm{kali} /$ minggu dengan kejadian PGK V besar risiko atau nilai $\mathrm{OR}=$
2,9 , terdapat hubungan antara merokok $\geq 10$ batang/hari dengan kejadian PGK V $(\mathrm{OR}=4,1)$, terdapat hubungan antara konsumsi obat herbal $>4 \mathrm{kali} /$ minggu dengan kejadian PGK V $(\mathrm{OR}=3,8)$, terdapat hubungan antara riwayat hipertensi dengan kejadian PGK V $(\mathrm{OR}=4,7)$, dan terdapat hubungan antara riwayat batu saluran kemih dengan kejadian PGK V $(\mathrm{OR}=3,8)$. Orang yang mengkonsumsi minuman suplemen energi $>4 \mathrm{kali} /$ minggu, merokok $\geq 10$ batang/hari, konsumsi obat herbal $>4$ $\mathrm{kali} /$ minggu, mempunyai riwayat hipertensi, dan mempunyai riwayat batu saluran kemih, memiliki probabilitas mengalami PGK V sebesar $96,8 \%$.

\section{Pembahasan}

Hasil analisis regresi logistik menunjukkan bahwa orang yang mengkonsumsi minuman suplemen energi $>$ 4 kali per minggu mempunyai risiko menderita PGK V sebesar 2,9 kali dibandingkan orang yang mengkonsumsi minuman suplemen $\leq 4$ kali per minggu. Hasil ini selaras dengan penelitian di Yogyakarta dan Gresik yang menyatakan bahwa konsumsi minuman suplemen energi mempunyai hubungan yang signifikan dengan kejadian PGK V.,

Beberapa zat psikostimulan (seperti taurin, amfetamin, kafein, ekstrak ginseng) yang terdapat dalam minuman supelemen energi dapat memperberat kerja ginjal. Zatzat tersebut jika dikonsumsi dalam jangka waktu yang lama dapat mempersempit pembuluh darah arteri ke ginjal sehingga darah yang menuju ke ginjal berkurang. Selain itu zat-zat lain yang terkandung dalam minuman suplemen energi seperti pemanis buatan (pada umumnya menggunakan aspartam), pewarna buatan, dan bahan pengawet, juga turut berperan merusak organ ginjal. ${ }^{9,10}$

Hasil analisis regresi logistik menunjukkan bahwa merokok 10 batang atau lebih ( $\geq 10$ batang) per hari, memiliki risiko menderita PGK V sebesar 4,1 kali lebih besar dibanding dengan orang yang 
merokok kurang dari 10 batang per hari. Hasil penelitian ini selaras dengan penelitian yang dilakukan oleh di Kulonprogo dan Ngawi. Efek merokok dapat meningkatkan pacuan simpatis yang akan berakibat pada peningkatan tekanan darah, takikardi, dan penumpukan katekolamin dalam sirkulasi. Pada fase akut beberapa pembuluh darah juga sering mengalami vasokonstriksi misalnya pada pembuluh darah koroner, sehingga pada perokok akut sering diikuti dengan peningkatan ketahanan pembuluh darah ginjal sehingga terjadi penurunan laju filtrasi glomerulus dan fraksi filter. ${ }^{11,12}$

Hasil analisis regresi logistik menyatakan bahwa orang yang mengkonsumsi obat herbal $>4$ kali per minggu memiliki risiko 3,7 kali lebih besar untuk menderita PGK V dibanding dengan orang yang mengkonsumsi obat herbal $\leq 4$ kali per minggu. Hal ini sesuai dengan penelitian yang dilakukan oleh di Taiwan bahwa konsumsi obat herbal merupakan salah satu faktor risiko kejadian PGK V. ${ }^{13}$

Banyak jenis produk herbal yang beredar di pasaran yang belum tentu aman dikonsumsi publik. Pengawasan terhadap obat herbal cenderung lebih longgar daripada obat-obatan medis. Padahal dalam berbagai kasus penyelidikan banyak ditemukan kandungan zat kimia berbahaya di dalam obat herbal yang dapat membahayakan organ tubuh manusia, terutama ginjal. Kandungan tersebut dapat berupa jenis logam berbahaya atau bahan kimia obat (BKO) yang mempunyai efek memperberat dan menurunkan fungsi ginjal. $^{13}$

Variabel yang diteliti dalam penelitian ini namun tidak terbukti sebagai faktor risiko PGK V yaitu konsumsi kopi, suplemen vitamin/mineral, minuman bersoda, alkohol, dan obat AINS. Hasil kualitatif melalui indepth interview diperoleh keterangan bahwa bahwa responden mengkonsumsi minuman suplemen energi untuk meningkatkan stamina, merokok karena sudah menjadi kebiasaan, dan mengkonsumsi obat herbal karena dipandang lebih alami dan cepat mengatasi masalah pegal linu.

Keterbatasan dalam penelitian ini yaitu potensi terjadi recall bias karena responden mengandalkan ingatan, di mana pada kelompok kasus akan cenderung mengingat faktor yang menyebabkan dia sakit, dan kelompok kontrol cenderung tidak mengingat faktor tersebut karena tidak menderita sakit. Selain itu dalam penelitian ini tidak dapat diketahui tentang zat spesifik yang terkandung dalam obat herbal yang berisiko menyebabkan PGK V serta tidak dapat diketahui berapa lama waktu yang diperlukan seseorang yang mengkonsumsi minuman suplemen energi, rokok, dan obat herbal untuk berisiko menderita PGK V.

\section{Kesimpulan}

Faktor risiko yang terbukti berpengaruh terhadap kejadian PGK stadium V pada kelompok usia kurang dari 50 tahun adalah konsumsi minuman suplemen energi $>4$ kali per minggu, Merokok $\geq 10$ batang per hari, Konsumsi obat herbal $>4$ kali per minggu setelah dikendalikan dengan riwayat hipertensi dan riwayat batu saluran kemih.

Hasil indepth interview responden memberikan keterangan bahwa responden mengkonsumsi minuman suplemen energi untuk meningkatkan stamina ketika bekerja, merokok karena sudah menjadi kebiasaan sejak remaja, dan mengkonsumsi obat herbal dipandang lebih alami dan cepat mengatasi keluhan pegal linu.

\section{Ucapan Terimakasih}

Terimakasih kepada pihak RSUD dr. H. Soewondo Kendal dan RSUD dr. Adhyatma, MPH Semarang yang telah memberikan ijin penelitian.

\section{Daftar Pustaka}

1. Suwitra K. Penyakit Ginjal Kronik. In: Sudoyo AW, Setiyohadi B, Alwi I, Simadibrata M, Setiati S. Buku Ajar Ilmu Penyakit Dalam. Jilid I. Jakarta: Pusat Penerbitan Departemen Ilmu 
Penyakit Dalam FKUI. 2007. p.570597

2. Sidabutar RP, Suhardjono, Kapojos EJ. Penyakit Ginjal Kronik. In: Soeparman, Waspadji S. Ilmu Penyakit Dalam. Jilid II. Jakarta: Balai Penerbit FKUI. 1996. p.349-389

3. Adrogue HJ, Wesson DE. Blackwell's Basics of Medicine; Renal Failure. USA: Blackwell Science. 1995. p.5097

4. International Society of Nephrology. Annual Data report. Kidney International Supplements (2015) 5,1; doi:10.1038/kisup. 2015

5. Indonesian Renal Registry. 7th Report of Indonesia Renal Registri. 2015. Available:

https://.indonesianrenalregistry.org (Accessed 1 Maret 2016)

6. Prakash S, O'Hare AM. Interaction of Aging and CKD. Semin Nephrol.2009. p.497-503

7. Centers for Disease Control and Prevention (CDC). National Chronic Kidney Disease Fact Sheet: General Information and National Estimates on Chronic Kidney Disease in the United States, 2014. Atlanta, GA: US Department of Health and Human Services, Centers for Disease Control and Prevention. 2014.

8. Bryman A. Penelitian Kuantitatif dan Kualitatif: Memandu Metode
Penelitian Kualitatif dan Kuantitatif, edisi 4. Samarinda: Pustaka Pelajar Ofset. 2002. p.81-105

9. Hidayati T. Hubungan hipertensi minuman suplemen energi dan merokok dengan kejadian penyakit ginjal kronik yang menjalani Hemodialisis di RSU PKU Muhammadiyah Yogyakarta. Studi Case Control. UGM. 2007.

10. Nugroho SHP. Hubungan Frekuensi Konsumsi Suplemen Energi Dengan Stadium CKD di Ruang Hemodialisis RSUD Ibnu Sina.Studi Cross Sectional. Gresik. Stikes Muhammadiyah Lamongan. 2014

11. Pranandari R, Supadmi W. Faktor Risiko Penyakit Ginjal Kronik di Unit Hemodialisis RSUD Wates Kulonprogo. Studi Casecontrol. Yogyakarta. Fakultas Farmasi Ahmad Dahlan. 2014

12. Restianika N. Faktor yang Berhubungan dengan Kejadian Gagal Ginjal Kronik di RSUD dr. Soeroto, Ngawi. Studi Case Control. UNEJ. 2014.

13. Guh CY, Chen HC, Tsai JF, Chuang LY. Herbal Therapy Is Associated With the Risk of CKD in Adults Not Using Analgesics in Taiwan. American Journal of Kidney Disease. 2007. 49 (5): 626-633 